\title{
Clomipramine and alprazolam to treat noise phobia in a dog: case report
}

\author{
Uso de clomipramina e alprazolam no tratamento \\ de cão com sensibilidade à ruídos: relato de caso
}

\author{
Lettycia Demczuk Thomas ${ }^{1 *}$ (D), Julyanna Demczuk Thomas ${ }^{1}$ (i), \\ Luciana Wolfran ${ }^{\circledR} \oplus$, Fabiola Bono Fukushima ${ }^{\circledR}$
}

\begin{abstract}
Behavioral disorders, including noise phobia, have a great impact on small animals internal medicine, impairing their quality of life as well as their life expectancy. The objective of this work is to report the case of a male dog who suffered from noise phobia and panic attacks triggered by thunderstorms and fireworks, and did not respond to previous training and treatment. After clinical and laboratory evaluations, he was treated with $2 \mathrm{mg} / \mathrm{kg}$ clomipramine twice daily for 90 days associated with $0.06 \mathrm{mg} / \mathrm{kg}$ alprazolam as needed on those days of intense fear. During the first week of treatment, a significant improvement could already be observed, with reduction in destructive behaviors, which lingered on for up to eight months of follow-up. The treatment stabilized the clinical condition and improved the patient's quality of life.
\end{abstract}

KEYWORDS: Noise phobia; Benzodiazepines; Tricyclic antidepressants

RESUMO: Os distúrbios de comportamento, entre eles o medo de ruídos, apresentam um grande impacto na clínica de pequenos animais, acarretando em decréscimo na qualidade e expectativa de vida. O objetivo deste trabalho é relatar o caso de um cão, macho, com histórico de medo de ruídos, que apresentava quadros de pânico desencadeados por trovões e fogos de artifício, sendo refratário a tentativas prévias de adestramento e tratamento medicamentoso. Após avaliação clínica e laboratorial, instituiu-se tratamento com clomipramina $2 \mathrm{mg} / \mathrm{kg}$ BID durante 90 dias associada à administração de alprazolam $0,06 \mathrm{mg} / \mathrm{kg}$ conforme necessário nos dias de medo intensificado. Na primeira semana de tratamento observou-se melhora significativa, com reduçáo dos comportamentos destrutivos, se estendendo até 8 meses de acompanhamento. O tratamento realizado proporcionou estabilizaçáo do quadro clínico e incremento na qualidade de vida do paciente. informação a ser inserida pelos autores.

PALAVRAS-CHAVE: Sensibilidade ao som; Benzodiazepínicos; Antidepressivos tricíclicos.

\section{INTRODUCTION}

Anxiety and phobias have become increasingly popular in small animals internal medicine. Separation anxiety, noise phobia, and difficulty in socializing are examples of the most common behavioral problems. It is estimated that $39.2 \%$ of dogs are sensitive to sounds (TIIRA et al., 2016). It is well-known that recurrent stress and daily fear and anxiety have a negative impact on the health and life expectancy of dogs (DRESCHEL, 2010).

Recent studies suggest a wide variety of treatments (behavioral management, pharmacotherapy and pheromones) for the management of phobias in small animals. The term phobia can be interpreted as accentuated fear, characterized by an immediate behavioral response and physiological signals, among which autonomic excitation, when exposed to the stimulus (SHERMAN; MILLS, 2008).

Fear activates the sympathetic nervous system by increasing the release of epinephrine and norepinephrine, which results in increased blood pressure and heart rate. The hypothalamic-pituitary-adrenal-cortical system is also recruited, causing an increase in blood cortisol levels. These changes lead to changes in behavior that can be presented in several forms (KING et al., 2003; PALESTRINI, 2009). In dogs, signs such as salivation, restlessness, tremors, vocalization, wheezing, and in some situations, urination and defecation, are observed in response to episodes of fear (PALESTRINI, 2009).

A variety of drugs have been described to treat phobia. Alprazolam is a benzodiazepine, which potentiates the action of 
GABA (gamma-aminobutyric acid), an inhibitory neurotransmitter in the central nervous system. These drugs have been in use in human medicine for some time to treat anxiety and panic attacks, and are now being used in veterinary medicine for the same purposes (SIMPSON; PAPICH, 2003). At the same time, a study showed negative results when sub-doses of alprazolam $(0.03-0.08 \mathrm{mg} / \mathrm{kg})$ was used as single drug to treat fear in dogs (OGATA; DODMAN, 2011).

Clomipramine is a more selective tricyclic antidepressant that acts by blocking serotonin reuptake (SIMPSON; PAPICH, 2003). Selective serotonin reuptake inhibitors drugs are effective in the treatment of depression and obsessivecompulsive disorders in humans, being also approved for the treatment of various behavioral disorders in veterinary medicine (FITZGERALD; BRONSTEIN, 2013).

The present work reports the case of a dog who presented recurrent panic attacks triggered by noise (fireworks and thunderstorms). The patient underwent evaluation, followed by treatment and veterinary medical monitoring, obtaining significant improvement and stabilization of the condition.

\section{CASE REPORT}

A six-year-old German Shepherd dog, weighing $33 \mathrm{~kg}$, with a history of altered behavior due to fireworks and thunderstorms was presented at the Hospital Veterinário da UFPR de Palotina-PR. The owner reported that ever since the adoption three years earlier, the dog has suffered from episodes of panic attack triggered by storms and fireworks.

According to the owner, during thunderstorms or firework events, the dog got agitated and sought refuge inside the house. The panic attack was initially characterized by panting and stereotyped gait, which progressed to generalized tremor, destructive behavior, self-inflicted trauma, self-defenestration, and even escape. During the episodes, the patient had anorexia, which could last for up to two days. Still according to the owner, the attacks were triggered by any degree of explosive noise (firecrackers, fireworks or thunderstorms). In addition to the impairment of the patient's quality of life, the condition directly affected the whole family, as they avoided leaving the house for any reason so as not to let their dog unattended, especially during Christmas and New Year's celebrations, when there is a greater occurrence of fireworks. During these periods, the dog showed the described altered behaviors for several days. The owner also described situations in which such altered behavior led the dog to start damaging furniture, doors and windows when left unsupervised.

The dog was refractory to behavioral reinforcement and training. Thus, during the panic attacks, the patient was treated with $0.4 \mathrm{mg} / \mathrm{kg}$ oral acepromazine, which relieved the signs of agitation for six to eight hours, but the panic attack recurred with every new stimulus.

Clinical evaluation was performed, including blood tests (albumin, alkaline phosphatase, alanine aminotransferase, creatinine, and urea), abdominal ultrasound and chest radiography, which did not show any changes. Based on the clinical evaluation, $2 \mathrm{mg} / \mathrm{kg}$ clomipramine was prescribed every 12 hours (BID) for 90 days. On days of higher occurrence of stressors, $0.06 \mathrm{mg} / \mathrm{kg}$ alprazolam was associated up to every eight hours (TID), depending on the degree of stress signs.

There was a significant improvement in the patient's behavior in the first week of treatment. According to the owner, within a few days of treatment, in the event of rain and fireworks, the patient entered the house, but did not show tremors or restlessness, remaining calm and returning to his natural routine as soon as the stimuli stopped. After the treatment was finished, the patient received periodic follow-up and the guardian did not report a single occurrence of breakouts, panic attacks or any of the aforementioned phobia behaviors for the subsequent eight months.

During the 90 days of treatment, the patient had no adverse effects such as drowsiness or vomiting. No appetite or behavioral changes were observed. The treatment improved the patient's quality of life and his relationship with the owners.

\section{DISCUSSION}

Currently, less than a third of owners of dogs presenting noise phobia seek veterinary assistance (BLACKWELL et al., 2013; STORENGEN; LINGAAS, 2015). It is known that fear reactions to lower noises (television, traffic) have an influence on the dog personality, while fear to louder noises (fireworks, shots) are secondary to repeated exposure or previous experiences. In addition, the sounds of fireworks and thunder, due to their unpredictable character, constitute an important stress stimulus, presenting great potential for the development of behavioral disorders such as exaggerated fear, panic and phobia. Studies point to a genetic influence on the occurrence of phobias and that some breeds may be predisposed to these disorders. In a non-randomized study that evaluated the prevalence, comorbidity and behavioral variation of dog anxiety, four breeds were found to be more prone to behavioral changes due to sound sensitivity, among them the German Shepherd (TIIRA et al., 2016; SOUZA; MEDEIROS, 2016).

Fears can be classified into three categories: simple fears, complex fears, and phobias. The latter can be compared to panic attacks. They can still be divided into two groups, according to their origin: development fears and learned fears. The first is due to exposure in the first months of life, successive stimuli or response to a later period of stress; whereas the second derives from a traumatic exposure or contact with another animal that shows phobia. After the initial evaluation of the patient, we concluded that, in the present work, the dog may have been exposed to stressful stimuli as a puppy and thus developed noise phobia. Responses to stressful stimuli may present as restlessness, tremors, destructive behavior, vocalization, self-mutilation, salivation and 
the seeking for shelter or people (MILLS, 2005; SOUZA; MEDEIROS, 2016), most of which could be perceived in the present report.

The behavior of the patient who suffers from sound sensitivity during episodes of fear may also differ according to their reproductive status. Neutered male dogs tend to exhibit active, preventive behaviors, such as those reported by the owner in the present case, where the dog sought protection, tried to escape and had tremors (TIIRA et al., 2016).

Taking into account the results of laboratory tests, the treatment was prescribed after a complete analysis of the patient's history. Then, a study on the described behavior was raised, reaching thus a specific final treatment for the case. The observed result corroborates the study by Crowell-Davis et al. (2003), who conducted a clinical trial with 40 dogs with a history of storm phobia, with 30 patients showing improvement in their condition after treatment similar to that performed in the present report.

Drug therapy for behavioral disorders in dogs must be specific, as the same treatment can have satisfactory effects in one group of patients and be ineffective for others (BEAVER, 2009). In dogs, clomipramine has been shown to be effective in treating separation anxiety, obsessive compulsive behaviors and noise fear at a dose of 1 to $2 \mathrm{mg} / \mathrm{kg}$, with only few cases of drowsiness or lethargy and vomiting (KING Et al., 2000; SEKSEL; LINDEMAN, 2001). These adverse effects are well reported in humans but were not observed in the present report.

It is worthy to emphasize the importance of being aware of the animals' behavior, since in most cases, the owners fail to identify the occurrence of these problems and their possible causes. Lack of veterinary assistance and treatment, combined with negative reinforcements that may be instituted aggravates the condition (BATISTA et al., 2018). According to Linhares et al. (2018), the owner's reaction to his dog presenting behavioral disorders is extremely relevant, as negative reinforcements such as reprimand or aggression can most certainly aggravate the condition and directly affect the psychological health of both the owner and the animal.

\section{CONCLUSIONS}

The present report highlights the importance of the diagnosis, treatment and monitoring of behavioral disorders in dogs. The patient showed a significant improvement with clomipramine and alprazolam, enabling greater quality of life and a better relationship with the owners.

\section{REFERENCES}

BATISTA, R. C.; TAVARES, L. P. D. V. B.; SILVA, A. S. A.; CUNHA, A. F. Alterações comportamentais em cães pela percepção de seus cuidadores. Revista Científica Univiçosa. v. 10, p. 977-981, 2018.

BEAVER, B. V. G. Canine Behavior: Insights and Answers. In: Canine Social Behavior. 2. ed. Elsevier Health Sciences, 2009.

BLACKWELL, E. J.; BRADSHAW, J. W. S.; CASEY, R. A. Fear responses to noises in domestic dogs: Prevalence, risk factors and co-occurrence with other fear related behavior. Applied Animal Behaviour Science, v. 145, p. 15-25, 2013.

CROWELL-DAVIS, S. L.; SEIBERT, L. M.; SUNG, W. et al. Use of clomipramine, alprazolam, and behavior modification for treatment of storm phobia in dogs. Journal of the American Veterinary Medical Association, v. 222, p. 744-748, 2003.

DRESCHEL, N. A. The effects of fear and anxiety on health and lifespan in pet dogs. Applied Animal Behaviour Science, v. 125, p. 157-162, 2010.

FITZCERALD, K. T.; BRONSTEIN, A. C. Selective Serotonin Reuptake Inhibitor Exposure. Topics in Companion Animal Medicine, v. 28, p. 13-17, 2013.

KING, J. N.; SIMPSON, B. S.; OVERALL, K. L. et al. Treatment of separation anxiety in dogs with clomipramine: results from a prospective, randomized, double-blind, placebo-controlled, parallelgroup, multicenter clinical trial. Applied Animal Behaviour Science, v. 67, p. $255-275,2000$.
KING, T.; HEMSWORTH, P. H.; COLEMAN, G. J. Fear of novel and startling stimuli in domestic dogs. Applied Animal Behaviour Science, v. 82, p. 45-64, 2003.

LINHARES, V. L. V.; SILVA, M. C.; SILVA, A. M.; BEZERRA, D. R. O adestramento positivo como tratamento em cães com distúrbios comportamentais de ansiedade: relato de caso. Publicações em Medicina Veterinária e Zootecnia, v. 12, p. 1-9, 2018.

MILLS, D. Management of noise fears and phobias in pets. Journal of British Veterinary Association, v. 27, p. 248-255, 2005.

OGATA, N.; DODMAN, N. H. The use of clonidine in the treatment of fear-based behavior problems in dogs: an open trial. Journal of Veterinary Behaviour, v. 6, p. 130-137, 2011.

PALESTRINI, C. Situational sensitivities. In: HORWITZ, D.; MILLS, D. S. BSAVA Manual of Canine and Feline Behavioural Medicine. Quedgeley, Gloucester: British Small Animal Veterinary Association, 2009.

SEKSEL, K.; LINDEMAN, M. J. Use of clomipramine in treatment of obsessive-compulsive disorder, separation anxiety and noise phobia in dogs: a preliminary, clinical study. Australian Veterinary Journal, v. 79, p. 252-256, 2001.

SHERMAN, B. L.; MILLS, D. S. Canine anxieties and phobias: an update on separation anxiety and noise aversions. Veterinary Clinics of North America: Small Animal Practice, v. 38, p. 10811106, 2008. 
SIMPSON, B. S.; PAPICH, M. G. Pharmacologic management in veterinary behavioral medicine. Veterinary Clinics of North America: Small Animal Practice, v. 33, p. 365-404, 2003.

SOUZA, C. C. F; MEDEIROS, M. A. Fatores de risco e transtornos comportamentais concomitantes em cães de companhia com medo exagerado a sons. Revista Brasileira de Medicina Veterinária, v. 38, p. 175-182, 2016
STORENGEN, L. M.; LINGAAS, F. Noise sensitivity in 17 dog breeds: Prevalence, breed risk and correlation with fear in other situations. Applied Animal Behaviour Science, v. 171, p. 152-160, 2015.

TIIRA, K.; SULKAMA, S.; LOHI, H. Prevalence, comorbidity, and behavioral variation in canine anxiety. Journal of Veterinary Behaviour, v. 16, p. 36-44, 2016. 